\title{
Service Innovation for Route Permits and Public Transport Operations Permits through Si Pintar Solo at the Surakarta City Department of Transportation
}

\author{
${ }^{1}$ Nina Septiani Safitri, Kristina Setyowati
}

\author{
${ }^{1}$ Universitas Negeri Sebelas Maret Surakarta, Indonesia; ninaseptianisafitri@student.uns.ac.id
}

Received: July 2, 2021; In Revised: October 21, 2021; Accepted: December 7, 2021

\begin{abstract}
Innovation is one way to restructure public services integrated with information technology. Starting from the existence of public transportation in Surakarta that is no longer extending due to the revitalization of public transportation, the lack of network and route permits optimization, and manual public transport permit services seem convoluted, slow and take a lot of time. Therefore, the Surakarta City Department of Transportation created the 'Si Pintar Solo' innovation, the Solo Route and Operation Licensing Information System. This study aims to identify and understand the implementation of the Si Pintar Solo innovation by using the innovation theory of Rogers (2003). This is descriptive qualitative research, with primary data, such as interviews and secondary data from related documents. The sample was selected by purposive sampling. The data validity used source triangulation. Finally, the data were analyzed using interactive analysis. The results showed that the Si Pintar Solo innovation implementation is described in each of the innovation attribute criteria, such as simplifying and accelerating services, because it is supported by adequate facilities and infrastructure, according to community needs. Furthermore, licensing is conducted online, which does not require coming to the Surakarta City Department of Transportation office and is integrated with the e-Uji service. In addition, it could monitor the licensing process, and the result of licensing data is stored in the database. However, there are obstacles, such as signal limitedness and the users' quandary about innovations involving technology.
\end{abstract}

Keywords: Innovation, public transport permit, public services

\section{Introduction}

A city that innovates by using information technology to overcome existing problems is often called a smart city. Using information technology can support government performance as a better, cheaper and faster target. Innovation in the public sector can be maximized as best as possible in terms of service because innovation is also the application of e-government which is considered capable of restructuring public services in the form of online information systems. In online-based public services, it also forms a mindset between the government as a manager and the community as users for good collaboration.

Several previous studies are considered relevant to the research, such as research conducted by (Pratama, 2018) entitled Input Process in Effectiveness of Inter-City Transport Route Permit Services Within Provinces. The Investment Board One-Stop Service West Java 
Province explained that the factors that influence the effectiveness of services are infrastructure, material factors related to data, capital factors, and human resource factors. Another study conducted by Suryanti \& Soegiarto (2017) entitled Application Model for Making KIR and Route Permits at the City Transportation Service Office explained that the application can speed up the making of KIR and route permits, the results of making KIR and route permits also provide reports- KIR and route data reports, and facilities are included backup. Then the research conducted by Nozomi \& Hamzah (2018) with the title Application for Data Processing of Goods Transport Business Permits at the Lima Puluh Regency Transportation Service Office explained that the application system makes it easier to process goods transport business license data, data security is more guaranteed by using a database, can minimize the time of the reporting process. Therefore, the resulting reports become effective and efficient.

Public transportation is one type of transportation used by the community to support daily activities. For people who do not have private vehicles, public transportation can be used as an alternative for mobility, goods, and services. A public transportation permit is a mandatory requirement that must be owned in its operation.

Permits in question are transportation business permits, route permits and public transportation operating permits. With this permit, it can provide guarantees for users of public transportation services to get appropriate services and provide protection to entrepreneurs of public transportation services to maintain a balance between supply and demand for transportation so that their business is maintained and developed. In addition, route permits and operating permits for public transportation can make it easier to manage claims in the event of an accident, make it easier to find out and regulate the number of public vehicles that have been licensed and can operate and regulate routes so that every public transportation that operates cannot pass through lanes outside the route.

Route licensing and public transport operations are a form of public service in the administrative field that produces various official documents such as Taxi Operation Permit Decrees, Operation Permit Extension Certificates, and Supervision Cards. Along with the growing needs and demands of the community for the quality of public services. The Ministry of State Apparatus Empowerment and Bureaucratic Reform has made a policy, One Agency One Innovation which requires each agency to create one innovation every year. This policy helps the community, especially in improving public services, because currently, public services must be integrated with information technology (Basuki, Kasmad, \& Nasrulhaq, 2018). According to Suwarno (2008), the quality of public services reflects the quality of the government bureaucracy, which is the result of a paradigm shift in public services. This requires innovation in the provision of public services to maximize innovation in the public sector as best as possible in terms of service. The Surakarta City Government realized this by creating various innovations into the top 10 Most in the Innovative City Governments in 2019 in Innovation Government Award.

The award cannot be separated from the role of each agency, one of which is the role of the Surakarta City Transportation Service. In terms of licensing routes and public transportation operations carried out by the Surakarta City Transportation Service, there are already regulations that regulate it, namely Surakarta City Regional Regulation Number 1 of 2013 concerning the Implementation of Transportation, article 152 explains that everybody or legal entity that does business in the field of public transportation In order to transport people, it is obligatory to complete a transportation business permit, route permit and operating license. However, starting with the problems in Surakarta itself, many public transportations no longer 
extend permits due to the revitalization of public transportation, network and route permits are not yet optimal. Before innovation was created in the service of route permits and public transport operating permits, the service was still done manually, which was considered convoluted, slow and time-consuming. Currently, many public services have restructured their services to integrate with information technology to make it easier and faster. Therefore, to overcome these problems, the Surakarta City Transportation Service created an innovation called Si Pintar Solo, which stands for the Route Licensing Information System and Solo City Operations. This online-based innovation provides several public transportations licensing services, which will begin to be served in mid-July 2019, indicating no more manual licensing services. The following is a list of conventional taxis and public transportation under the auspices of the Surakarta City Transportation Service:

Tabel 1

Number of Public Transport Vehicles in Surakarta City in 2014-2018

\begin{tabular}{cccccc}
\hline & \multicolumn{5}{c}{ Year } \\
\cline { 2 - 6 } Type of vehicle & 2014 & 2015 & 2016 & 2017 & 2018 \\
\hline Taxi & 828 & 828 & 772 & 790 & 681 \\
\hline City transportation & 380 & 380 & 247 & 247 & 1655 \\
\hline
\end{tabular}

Source: Surakarta City Transportation Office 2019

Table 1 explains that public transportation in Surakarta City, namely taxis, has decreased to 681 fleets. Meanwhile, city transportation has increased to 1655. The two types of fleets can access the application Si Pintar Solo because they are still under the authority of the Surakarta City Transportation Service.

Based on the described background, it strengthens the researcher that public services that have been supported by information technology are one way to improve the quality of public services. Likewise, the Surakarta City Transportation Service has created Si Pintar Solo's application to improve route permit services and public transport operating permits. For more details, the researchers will conduct research related to implementing service innovations for route permits and public transport using tickets through Si Pintar Solo at the Surakarta City Transportation Service. This study aims to determine the implementation of service innovations for route permits and operating permits for public transportation through Si Pintar Solo. In order to be able to contribute ideas and increase knowledge in the study of State Administration by using the theory of implementing innovation according to Rogers (2003) where there are five attributes to be studied, namely relative advantage, compatibility, complexity, liability, observability.

\section{Methods}

The method used is descriptive qualitative because this study wants to explain or describe the implementation of service innovations for route permits and public transport operating permits through Si Pintar Solo. The selection of informants was carried out by purposive sampling, which was determined directly by the researcher, who could provide in-depth data and information and could be trusted to be a good source of data. The resource persons in this study were the Head of the Transportation Division, the Head of the People's Transportation Section, the Staff of the Transportation Division and the Public Transport Company. Data 
collection techniques using interview techniques, observation and documentation techniques. The validity of the data using triangulation of sources by checking the data obtained through several sources and triangulation of methods through interviews and then matched with the findings during observation and documentation. According to Miles and Huberman, data analysis using interactive analysis consists of data collection, data reduction, data presentation, and concluding.

\section{Results and Discussion}

Initially, innovation was identical in business organizations, but the development of science and technology and very tight competition demanded the government to make changes to create service quality (Ulfa \& Sulfiani, 2018). This is further explained by Salge \& Vera (2012) that the fundamental value of the public sector is customer-oriented. Customer needs and satisfaction is top priority in providing services. According to Mirnasari (2013), innovation in public services has an intangible characteristic because service and organizational innovation are not solely based on products that cannot be seen. But on a change in the relationship of the perpetrators, namely the service provider () and service receiver (user). More specifically, the notion of public service innovation can be interpreted as achieving, improving, and improving the effectiveness, efficiency and accountability of public services generated by the initiative of new methodological approaches or tools in public services. According to Said (2007), innovation is a planned change by introducing technology and using new equipment within the scope of work in an agency supported by other relevant agencies or improving a more efficient way of working by integrating social resources and employee resources and human resources institutional.

According to Mulgan \& Albury in Muluk (2008), innovation is successful innovation is the creation and implementation of new processes, products, services, and methods of delivery which result in significant improvement in outcomes efficiency, effectiveness, or quality. This means that successful innovation is the creation and implementation of new processes, products, services, and methods that can significantly improve efficiency, effectiveness, or quality of results. The statement suggests that innovation should be the core of activity in the public sector, thereby improving performance effectively and efficiently. For the government, innovation in public services is significant to create good value for the community. Service innovation is one form of bureaucratic reform in public services. The development of science and information technology requires that public services be integrated with information technology. Especially now that public services with digital concepts are demanded to be easier, faster, more precise, accountable and transparent. The city of Surakarta is one area that has improved its public services by creating various innovations. Such as the innovation of route permit services and public transportation operations initiated by the Surakarta City Transportation Service.

The Surakarta City Transportation Service is an agency in charge of carrying out government affairs in the field of transportation and has the authority to issue transportation business permits, public passenger transportation permits, goods transportation permits, issuance of route permits and public transportation supervision cards, shuttle transportation route permits, transportation operating permits. Rental, tourism transportation using tickets, Route Permit Approval, Operational Permit Approval Inter-City Within Province Taxi Transport and others. In this regard, the Surakarta City Transportation Service created an innovation called Si Pintar Solo, namely the Solo City route and operation permit information 
system. This innovation is an innovation in the field of service for route permits and androidbased public transport operating licenses in Surakarta. Before the innovation of Si Pintar Solo, route licensing and public transport operations were done manually by coming directly to the Surakarta City Transportation Service office and bringing the documents for licensing requirements. However, after creating Si Pintar Solo, route licensing and public transport operations were changed to an online-based service system by only accessing the website. http://sipintarsolo.surakarta.go.id/ using a computer or mobile phone.

In the application, Si Pintar Solo, services that can be carried out are the extension of route permits and public transportation operations, issuance of a Decree to increase the fleet of route permits and public transportation operations extension of the Supervision Card. The purpose of this innovation was created to simplify and speed up the transportation permit service process in the city of Surakarta, especially for public transportation companies. However, not all people can access this application because route permits and public transport operating permits cannot be done individually. Instead, it must be carried out by a business entity such as a cooperative or a limited liability company (PT) that oversees the yellow plate public transportation fleet. In addition, the existence of Si Pintar Solo aims to make it easier to manage KIR, monitor roadworthiness status and vehicle taxes owned.

In order to access this service, the applicant must register first, which will later receive a username and password. Then the applicant logs in using the username and password that has been obtained to fill out the permit application form and upload the documents for the permit requirements. Then the submitted permit will be verified by the officer. After it is stated that the documents and requirements are complete, the applicant just needs to take the permit results file such as the Decree, attachments and Supervision Card at the Surakarta City Transportation Office. The implementation of service innovations for route permits and operating permits for public transportation through Si Pintar Solo at the Surakarta City Transportation Service was analyzed using innovation theory according to Rogers (2003).

According to Suwarno (2008), innovation has a fundamental nature, namely the nature of novelty that replaces old knowledge, methods, objects, technologies or inventions that are no longer effective in solving a problem or answering a particular need. In implementing innovation, there are five attributes or characteristics proposed by Rogers (2003), namely the first relative advantage, meaning that innovation has benefits and more value than previous innovations. There is always an inherent novelty value in an innovation that characterizes and distinguishes it from others. Second, compatibility means that innovations are created according to the innovations being replaced, so that old innovation is not abandoned. Because old innovations are part of the transition process to innovations and can also facilitate adapting and learning techniques to these innovations more quickly. Third, complexity means that with its new nature, innovation has a level of sophistication that may be higher than previous innovations. Fourth, liability means that innovation can only be accepted if tested and proven to have advantages or more value than previous innovations. Fifth, observability means that innovation must be observable in terms of how the innovation works and produces something better. Each attribute has the criteria described in Table 2 below: 
Table 2

Criteria for Innovation Attributes According to Rogers

\begin{tabular}{|c|c|c|}
\hline No. & Variable & Criterion \\
\hline \multirow[t]{4}{*}{1} & Relative advantage & Comfortable in using \\
\hline & & Prestige/differentiation \\
\hline & & Work faster \\
\hline & & Work easier \\
\hline \multirow[t]{3}{*}{2.} & Compatibility & Conformity with community needs \\
\hline & & $\begin{array}{l}\text { Conformity with values and past } \\
\text { experiences }\end{array}$ \\
\hline & & Conformity with adopter's beliefs \\
\hline \multirow[t]{4}{*}{3.} & Complexity & Easy to learn \\
\hline & & Easy understood \\
\hline & & Easy to use \\
\hline & & Flexible \\
\hline \multirow[t]{2}{*}{4.} & Trialability & Can be tried \\
\hline & & Easy to find ways to use it \\
\hline \multirow[t]{3}{*}{5.} & Observability & Easy to observe \\
\hline & & $\begin{array}{l}\text { Easy to communicate with others } \\
\text { Other }\end{array}$ \\
\hline & & People can feel the benefits \\
\hline
\end{tabular}

Source: (Sugandini, 2009)

\section{Relative advantage}

This attribute compares a newly created innovation with the previous innovation because it aimed to gain advantages and added value that characterizes and distinguishes it from the last services. The innovation of route permit services and public transport operating permits through Si Pintar Solo has met the four criteria. First, the requirements for comfort in use explain that they are supported by adequate facilities and infrastructure, such as the availability of software, namely the application Si Pintar Solo and a database owned by the Surakarta City Transportation Service. Furthermore, there is hardware such as wifi or internet quota for convenient internet access, computers, CPUs, HP to carry out route permits and operating permits through Si Pintar Solo. 
Second, the prestigious criteria explain the difference in the system. Previously, the service was done manually by coming to the Surakarta City Transportation Office, but with the Smart Solo, licensing can be done online. Another difference lies in inaccessibility, the reduced face-to-face access between officers and service users because it does not require a physical arrival to the Surakarta City Transportation Office. Furthermore, with the implementation of service innovations for route permits and public transportation operating permits through $\mathrm{Si}$ Pintar Solo, the third criterion, namely working faster, is also fulfilled. This is because all licenses such as extending route permits, extending supervision cards, adding public transport fleets can be done online. Then it can also reduce human resources because officers and users are all involved. In addition, the licensing period was also shortened to two days after the permit had been completed.

In the fourth criterion, namely working more efficiently, it is explained that all forms of licensing data are stored in the database, the Surakarta City Transportation Services, such as the list of Operational and Route Decrees that apply in Surakarta City. This makes it easier to check the required data and store it safely. For example, the following is one of the public transportation licensing databases owned by the Surakarta City Transportation Service:

Figure 1

Public Transportation Licensing Database 2020

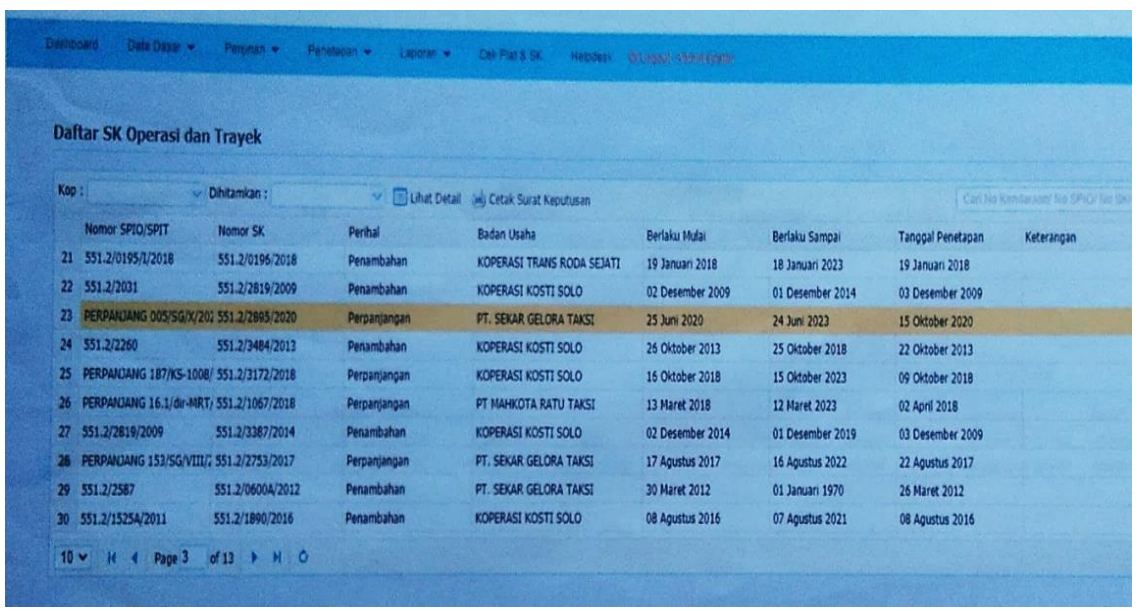

Source: Surakarta City Transportation Service 2020

\section{Compatibility}

Discussed the compatibility of innovations created with previous innovations, so that old innovation is not abandoned. It is explained in the first criterion, namely conformity to the community's needs. It is demonstrated that the innovation of Si Pintar Solo is in accordance with the community, especially public transport entrepreneurs. Si Pintar Solo makes it easier for public transportation companies to fulfil their normative obligations. Second, the criteria for conformity of innovation with past values and experiences explained that basically, the licensing remains the same. There are no changes in requirements like the manual service used to be. Because creating innovation is the Si Pintar Solo course guided by the previous service. In the past, manual service was cumbersome because you had to come to the Transportation Service Office, now it has been changed to a system, namely Si Pintar Solo. Here is the display from the Si Pintar Solo website. 
Figure 2

Si Pintar Solo website

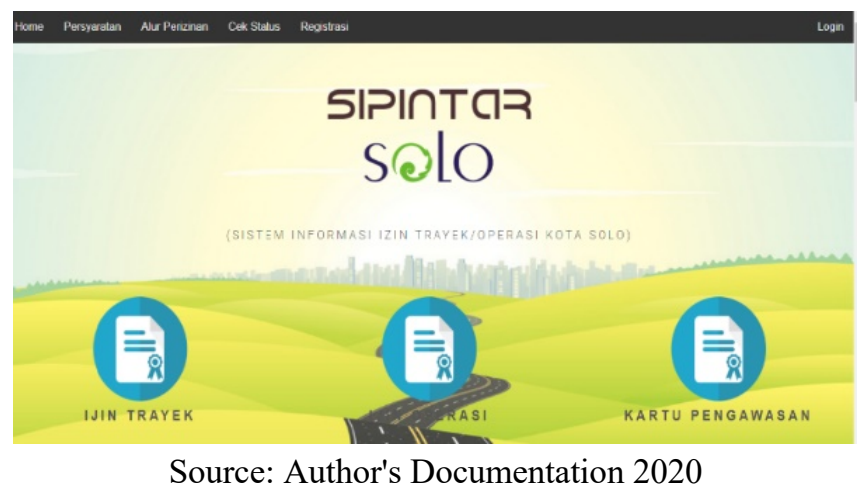

Figure 2 explains three services that can be accessed on the Si Pintar Solo website, namely route permit services, operating permits, and supervision cards. The third criterion, namely conformity with the belief of the adopter, explained that it was in accordance with the expectations of service providers because with the innovation Si Pintar Solo, all licensing data was stored in the database. So, it helps if you want to find data, check data, and make reports.

\section{Complexity}

It is explained that some complexities could be called constraints in implementing innovation Si Pintar Solo. In terms of easy-to-learn criteria, both officers and users find it easy to learn because the essential services remain the same. The number of public transportation fleets in Surakarta City is also not significant. The constraints experienced are even on the internet network that users feel due to signal limitations. The following criterion is easy to understand. There are obstacles due to limited human resources from service users in understanding innovation Si Pintar Solo's, being impatient, and not wanting to be complicated. Then the easy-to-use criteria are explained through Si Pintar Solo. Route permit services and public transport operating permits are made more accessible because you just need to log in and fill out the registration form, then the officers just need to verify it. However, for printing Decision Letters and Supervision Cards, you still have to come to the Transportation Service Office. Permit applicants cannot print themselves because the printing will coincide with the payment of a levy. The last criterion is flexibility, explained by the innovation of Si Pintar Solo, which can save time because there is no need to come to the Surakarta City Transportation Service, save costs on the activities carried out, and be flexible it is integrated with e-Uji.

\section{Liability}

Discusses innovations that society can accept are the innovation that has stood the test. So, it is explained in the first criterion, namely that innovation can be tried, presented before the innovation of Si Pintar Solo is launched. It has been tested to users by providing information and introducing how to implement Si Pintar Solo. However, when tested, users were not so enthusiastic. So, when it was launched, it invited several stakeholders from the Surakarta City Transportation Service and public transportation companies to introduce more Solo Smart. Then on the innovation of Si Pintar Solo, it is easier for users to find ways to use it because the mechanism or licensing flow is explained on the website of Si Pintar Solo itself. Here is the flow of licensing through Si Pintar Solo: 
Figure 3

Licensing Procedures through Si Pintar Solo

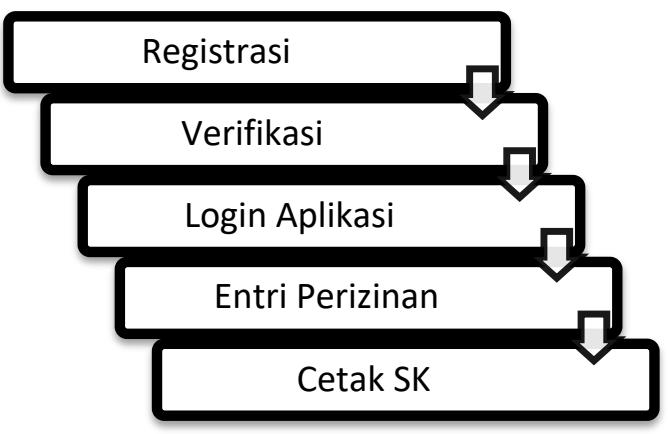

Source: sipintarsolo.surakarta .go.id

\section{Observability}

Explaining Related innovation must be readily observed in terms of how these innovations work. The first criterion is the ease of observation, indicated by how officers can view the fleet data stored in the database. Then users can also monitor to what extent the licensing process is carried out. The second criterion is the ease of communication with other people, as seen from users' lack of understanding, such as employees at PT. TGM employees are old, so to be faced with innovations that involve technology, they feel confused. Sometimes public transport drivers themselves do the licensing. The owner of the company is obliged to carry out the permit, and it cannot be done individually. The third criterion, namely that other people can feel the benefits, is explained after implementing the innovation Si Pintar Solo. The benefits obtained are providing certainty, speed of service and ease of service both in officers and service users. Finally, there is hope in the future, namely the integration of the Online Tax Vehicle Administration System application and developing a retribution payment method, namely via transfer or e-payment.

\section{Conclusion}

The implementation of innovation is Si Pintar Solo's going quite well, which can be described in every attribute of innovation according to Rogers (2003). The innovation of Si Pintar Solo provides the benefits of certainty, speed and ease of service for route permits and public transport operating permits at the Surakarta City Transportation Service. However, there are obstacles on the internet network that sometimes experience signal limitations, and users do not understand technology. For these obstacles, the advice given is to improve the internet network by increasing internet speed or using a provider with a good signal and socializing to service users massively by inviting public transport service entrepreneurs or installing banner a licensed service through Si Pintar Solo, which is displayed at the Transportation Service Office. Surakarta City. This research is expected to provide information and understanding to public transportation companies related to the implementation of innovation. The Solo Smart can give input and contribute ideas to the Surakarta City Transportation Service to continue to improve and evaluate route permit services and public transport operating permits. For further research, it can be used as a reference with a similar topic and can be further investigated regarding the effectiveness of the application of Si Pintar Solo. 


\section{References}

Basuki, Y., Kasmad, R., \& Nasrulhaq. (2018). Tipologi Inovasi Publik (Inovasi Program SICAKEP) di Kabupaten Wajo, Sulawesi Selatan. Matra Pembaruan, 2(3), 209.

Mirnasari, R. M. (2013). Inovasi Pelayanan Publik UPTD Terminal Purabaya-Bungurasih. Kebijakan dan Manajemen Publik, 1(1), 77.

Muluk, M. K. (2008). Knowledge Management: Kunci Sukses Inovasi Pemerintah Daerah. Malang: Banyumedia.

Nozomi, I., \& Hamzah, M. L. (2018). Aplikasi Pengolahan Data Surat Izin Usaha Angkutan Barang Pada Kantor Dinas Perhubungan Kabupaten Limapuluh. Journal of Information Technology and Computer Science, 1(1), 110-118.

Pratama, A. (2018). Proses Input Dalam Efektivitas Pelayanan Izin Trayek Angkutan Antar Kota Dalam Provinsi (Akdp) Online Di Dinas Penanaman Modal Dan Pelayanan Terpadu Satu Pintu (DPMPTSP) Provinsi Jawa Barat . Jurnal Aksi Reformasi Government dalam Demokrasi, 6(2), 126-137.

Rogers, E. M. (2003). Diffusion of Innovations 5th edition. New York: Free Press.

Said, M. M. (2007). Birokrasi di Negara Birokratis. Malang: UMM Press.

Salge, T. O., \& Vera, A. (2012). Benefiting from Public Sector Innovation: The Moderating Role of Customer and Learning Orientations. Public Administration Review, 550560 .

Suryanti, A., \& Soegiarto. (2017). Model Aplikasi Pembuatan Perijinan KIR Dan Trayek Pada Kantor Dinas Perhubungan Kota. JUSTISI, 6(2), 1449-1588.

Suwarno, Y. (2008). Inovasi di Sektor Publik. Jakarta: STIA-LAN Press.

Ulfa, \& Sulfiani, A. N. (2018). Inovasi Sistem Informasi Manajemen Administrasi Perizinan di Dinas Penanaman Modal dan Pelayanan Terpadu Satu Pintu Kota Palopo. Jurnal Administrasi Negara, 24(2), 134. 